\title{
HB-Line Dissolution of Glovebox Floor Sweepings
}

by

J. H. Gray

Westinghouse Savannah River Company

Savannah River Site

Aiken, South Carolina 29808

This paper was prepared in connection with work done under the above contract number with the U. S.

Department of Energy. By acceptance of this paper, the publisher and/or recipient acknowledges the U.S. Government's right to retain a nonexclusive, royalty-free license in and to any copyright covering this paper, along with the right to reproduce and to authorize others to reproduce all or part of the copyrighted paper. 


\section{DISCLAIMER}

This report was prepared as an account of work sponsored by an agency of the United States Government. Neither the United States Government nor any agency thereof, nor any of their employees, makes any warranty, express or implied, or assumes any legal liability or responsibility for the accuracy, completeness, or usefulness of any information, apparatus, product, or process disclosed, or represents that its use would not infringe privately owned rights. Reference herein to any specific commercial product, process, or service by trade name, trademark, manufacturer, or otherwise does not necessarily constitute or imply its endorsement, recommendation, or favoring by the United States Government or any agency thereof. The views and opinions of authors expressed herein do not necessarily state or reflect those of the United States Government or any agency thereof.

This report has been reproduced directly from the best available copy.

Available to DOE and DOE contractors from the Office of Scientific and Technical Information, P.O. Box 62, Oak Ridge, TN 37831; prices available from (615) 576-8401.

Available to the public from the National Technical Information Service, U.S. Department of Commerce, 5285 Port Royal Road, Springfield, VA 22161. 


\section{DISCLAIMER}

Portions of this document may be illegible electronic image products. Images are produced from the best available original document. 


\section{HB-Line Dissolution of Glovebox Floor Sweepings (U)}

\section{By}

\section{John H. Gray}

Issued: February 1998

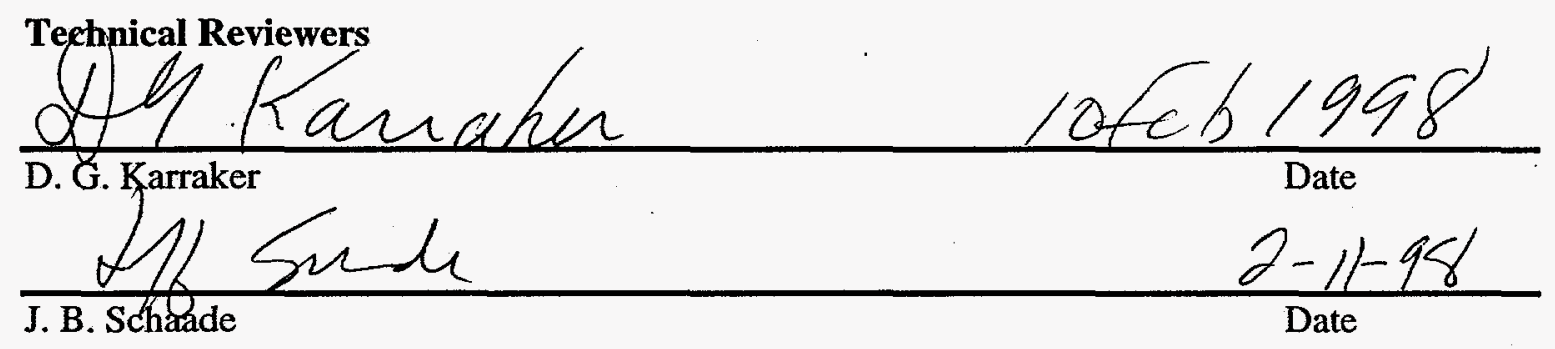

\section{UNCLASSIFIED \\ DOES NOT CONTAIN \\ UNCLASSIFIED CONTROLLED}

$A D C$ \&

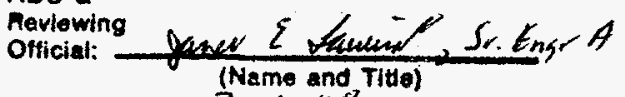

Date: $2 \cdot 10-48$

Westinghouse Savannah River Company

Building 773-A

Aiken, SC 29808

Prepared for the U. S. Department of Energy under Contract DE-AC09-96SR18500 


\section{Table of Contents}

Section

Page

Summary

The Selected Flowsheet.

Introduction

Experimental.

Dissolution Studies.

Discussion

Glovebox Floor Sweepings Dissolution Flowsheets.

Experiment \#1.0.

Experiment \#2.0.

Experiment $\# 2 \mathrm{~B}$

Experiment \#3.0

Experiment \#3A

Experiment \#3B and \#3C.

Experiment \#4.0 and \#4A....................................... 5

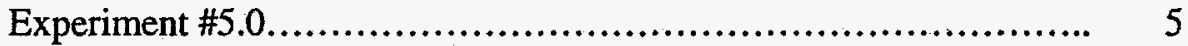

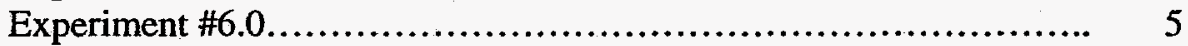

Experiment \#6A and \#6B.......................................... 5

Experiment \#7.0, \#7A, and \#7B.................................. 5

Experiment \#8.0, \#8A, and \#8B.................................. 5

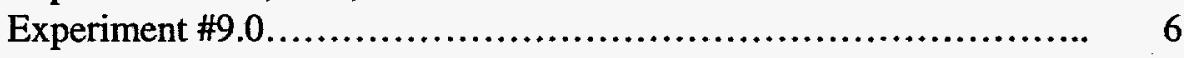

Conclusions....................................................................... 6

References..................................................................... 7

\section{List of Tables}

Table 1 
WSRC-TR-98-00029

Revision 0

\title{
HB-Line Dissolution of Glovebox Floor Sweepings (U)
}

\author{
John H. Gray \\ Westinghouse Savannah River Company \\ Savannah River Site \\ Aiken, SC 29808
}

\section{Summary}

Two candidate flowsheets for dissolving glovebox floor sweepings in the HB-Line Phase I geometrically favorable dissolver have been developed. Dissolving conditions tested and modified during the laboratory program were based on the current processing scheme for dissolving high-fired Pu-238 oxide in HB-Line. Subsequent adjustments made to the HB-Line flowsheet reflected differences in the dissolution behavior between high-fired Pu-238 oxide and the $\mathrm{MgO}$ sand $/ \mathrm{PuF}_{4} / \mathrm{PuO}_{2}$ mixture in glovebox floor sweepings.

Although both candidate flowsheets involved two separate dissolving steps and resulted in complete dissolution of all solids, the one selected for use in HB-Line will require fewer processing operations and resembles the initial flowsheet proposed for dissolving sand, slag, and crucible material in F-Canyon dissolvers (Ref. \#1). Complete dissolution of glovebox floor sweepings was accomplished in the laboratory by initially dissolving between 55 and $65^{\circ} \mathrm{C}$ in a 14 molar nitric acid solution. Under these conditions, partial dissolution of $\mathrm{PuF}_{4}$ and complete dissolution of $\mathrm{PuO}_{2}$ and $\mathrm{MgO}$ sand were achieved in less than one hour. The presence of free fluoride in solution, uncomplexed by aluminum, was necessary for complete dissolution of the $\mathrm{PuO}_{2}$. The remaining $\mathrm{PuF}_{4}$ dissolved following addition of aluminum nitrate nonahydrate (ANN) to complex the fluoride and heating between 75 and $85^{\circ} \mathrm{C}$ for an additional hour.

Precipitation of magnesium and/or aluminum nitrates could occur before, during, and after transfer of product solutions. Both dilution and/or product solution temperature controls may be necessary to prevent precipitation of these salts. Corrosion of the dissolver should not be an issue during these dissolving operations. Corrosion is minimized when dissolving at $55-65^{\circ} \mathrm{C}$ for one to three hours at a maximum uncomplexed free fluoride concentration of 0.07 molar and by dissolving at $75-85^{\circ} \mathrm{C}$ at a one to one aluminum to fluoride mole ratio for another one to three hours. Generation of hydrogen caused by the dissolution of calcium metal should also not be a concern. No hydrogen was detected in the laboratory off-gas stream and insignificant metals of any kind are present in glovebox floor sweepings. 


\section{The Selected Flowsheet}

The flowsheet selected by HB-Line for dissolving glovebox floor sweepings will involve the following processing operations.

(1) Addition of a maximum of 1500 grams of scrap, with a maximum of 1000 grams of $\mathrm{Pu}$ as $\mathrm{PuF}_{4} / \mathrm{PuO}_{2}$, to 15 liters of $64 \%$ nitric acid.

(2) Heating between $55-65^{\circ} \mathrm{C}$ for a minimum of two hours.

(3) Addition of five liters of $34 \mathrm{wt} . \%$ aluminum nitrate.

(4) Heating between $80-85^{\circ} \mathrm{C}$ for a minimum of two hours.

(5) Performing subsequent transfer, dilution, and flushing operations such that solids will not precipitate in any of the transfer lines or process vessels.

\section{Introduction}

Glovebox floor sweepings are generated at Savannah River in FB-Line during preparation of the feed material used in the metal producing bomb reduction process. It is usually after precipitation and during drying or conversion of plutonium fluoride to a $\mathrm{PuF}_{4}-\mathrm{PuO}_{2}$ mixture at $500^{\circ} \mathrm{C}$, that spills occur which can contaminate the converted cake with varying amounts of $\mathrm{MgO}$ sand or other glovebox materials. This contaminated converted cake mixture of $\mathrm{PuF}_{4}$ and $\mathrm{PuO}_{2}$ is packaged and stored in the vault for eventual recovery of the plutonium.

In the past, most recovery operations in $\mathrm{HB}$-Line have dealt with $\mathrm{PuO}_{2}$ as the only plutonium compound present in the material to be dissolved. However, since the plutonium in FB-Line glovebox floor sweepings is a mixture of plutonium fluoride $\left(\mathrm{PuF}_{4}\right)$ and plutonium oxide $\left(\mathrm{PuO}_{2}\right)$, the standard HB-Line dissolving flowsheet is not directly suitable for complete dissolution. This is because it is difficult to completely dissolve $\mathrm{PuO}_{2}$ when the fluoride is complexed with aluminum and it is difficult to completely dissolve $\mathrm{PuF}_{4}$ unless sufficient aluminum is present to complex free fluoride. These observations were previously confirmed during the initial flowsheet development work for dissolving sand, slag, and crucible materials in F-Canyon dissolvers. 


\section{Experimental}

Samples of the converted cake and $\mathrm{MgO}$ sand were obtained from FB-Line operations. Before laboratory studies were initiated, both materials were characterized by using Scanning Electron Microscopy (SEM) and X-Ray Diffraction (XRD) for determining particle size distributions, impurities present, and compound weight ratios, by using gas chromatography for measuring hydrogen generation, and by using weight loss differences and material balances for moisture content.

Most of the converted cake particles ranged in size from one to ten microns with the maximum particle size about 12 microns. About $95 \%$ of the $\mathrm{MgO}$ particles ranged in size from 100 to 700 microns. The XRD scans found between $70-75$ wt. $\%$ of the converted cake was $\mathrm{PuF}_{4}$ with the remaining 25-30 wt.\% being $\mathrm{PuO}_{2}$. Assuming a $75 \mathrm{PuF} 4 / 25 \mathrm{PuO}_{2}$ wt.\% ratio, material balance calculations found the moisture content to be $7.0 \pm 1.0 \mathrm{wt} . \%$. At a $70 / 30 \mathrm{wt} . \%$ ratio, the moisture content would be about $8.0 \pm 1.0 \mathrm{wt} . \%$. A final mass distribution of $69.7 \mathrm{wt}$.\% PuF4, $23.3 \mathrm{wt} . \%$ $\mathrm{PuO}_{2}$, and $7.0 \mathrm{wt} . \%$ moisture was later confirmed from plutonium and fluoride material balance measurements. Other impurities present in the converted cake and $\mathrm{MgO}$ samples were insignificant. No metal impurities were present in the sample of converted cake and no hydrogen was detected in the gas sample collected after dissolution in a nitric acid solution.

\section{Dissolution Studies}

The series of laboratory dissolution experiments was conducted by adding batches of converted cake and $\mathrm{MgO}$ sand to a glass beaker dissolver at selected solids to liquid ratios. In all experiments the initial solution composition was nitric acid or a combination of nitric acid and aluminum nitrate. Fluoride as $\mathrm{HF}$ or $\mathrm{KF}$ was not added since all the fluoride needed to dissolve $\mathrm{PuO}_{2}$ was generated from dissolved $\mathrm{PuF}_{4}$. The dissolver beakers containing the solutions and solids were placed on a hot plate, gently agitated, heated at selected temperatures, the temperatures were controlled by adjusting hot plate settings, and the time and conditions necessary for complete dissolution of all solids recorded. The solids dissolution time was measured as a function of solution concentration, solids to liquid ratio, and temperature. Although the intent was to completely dissolve all solids with a minimum number of process operations, this mixture of nitrates, fluorides, and oxides required a number of flowsheet adjustments before all solids remained completely dissolved.

\section{Discussion}

\section{Glovebox Floor Sweepings Dissolution Flowsheets}

Objectives of the dissolution experiments were to identify flowsheet conditions necessary for complete dissolution of all solids and to be able to use flowsheet steps compatible with HB-Line dissolver operations. Each group of laboratory experiments started out by adding solids at different mass to volume ratios to nitric acid solutions. When all solids were not completely dissolved under the initial conditions, subsequent adjustments were made until all solids dissolved and remained dissolved. Each subsequent adjustment was made to resolve a particular issue and conclusions reached were based on results after each adjustment. A complete summary of dissolution conditions, observations made, and results obtained for each set of experiments 
conducted is presented in Table $\mathrm{I}$. The following discussions are based on information provided in this Table.

\section{Experiment \#1.0}

This initial experiment was a screening study to establish if this $\mathrm{PuF}_{4}-\mathrm{PuO}_{2}$ mixture could dissolve completely in nitric acid without fluoride or aluminum initially present. It was anticipated that any fluoride ions coming from the partial dissolution of $\mathrm{PuF}_{4}$ would dissolve all the $\mathrm{PuO}_{2}$, which did occur. $\mathrm{All} \mathrm{PuF}_{4}$ solids were dissolved without aluminum present because the $\mathrm{PuF}_{4}$ solubility limit had not been reached.

\section{Experiment \#2.0}

This experiment increased the solids to liquid ratio by a factor of ten to 50 grams per liter. Although all the $\mathrm{PuO}_{2}$ dissolved, due to the partial dissolution of $\mathrm{PuF}_{4}$, most of the $\mathrm{PuF}_{4}$ remained undissolved because of the limited solubility of $\mathrm{PuF}_{4}$ in nitric acid when aluminum is not present to complex fluoride.

\section{Experiment \#2A}

Experiment \#2A was a continuation of \#2.0 by adding ANN to complex fluoride ions and complete the dissolution of remaining $\mathrm{PuF}_{4}$ solids. After the solution cooled to room temperature, white solids were present which could have been ANN crystals forming at lower temperatures.

\section{Experiment \#2B}

If the solids were ANN crystals, increasing the volume by adding a nitric acid solution should redissolve them. When the white solids remained, a SEM scan identified them as a silicon compound, from the glass beaker,which is insoluble in nitric acid, and not ANN.

\section{Experiment \#3.0}

This experiment was the first attempt to dissolve all solids at a high mass to volume ratio when ANN was present in the nitric acid solution. Although all the $\mathrm{PuF}_{4}$ may have dissolved in the ANN solution due to the complexing of fluoride with aluminum, most (all) of the $\mathrm{PuO}_{2}$ remained undissolved.

\section{Experiment \#3A}

This continuation of experiment \#3.0 was an attempt to determine if any $\mathrm{PuF}_{4}$ remained undissolved and if any additional $\mathrm{PuO}_{2}$ would slowly dissolve by extending the heating cycle at boiling temperatures. Plutonium analysis results confirmed no additional plutonium had dissolved.

\section{Experiments \#3B and \#3C}

Results for these two experiments identified the first set of flowsheet conditions necessary for complete dissolution of all solids. It required separation of the ANN solution from remaining $\mathrm{PuO}_{2}$ solids and established the need for uncomplexed fluoride in solution. Since this two-step 
dissolution flowsheet was labor intensive and required the complete removal of aluminum from the dissolver, the next set of experiments (\#s 4.0 and 4A) was designed to change conditions to minimize the number of process operations for complete dissolution of solids.

\section{Experiments \#4.0 and \#4A}

This set of experiments demonstrated that the first step in a two step dissolution flowsheet should be dissolution of the $\mathrm{PuO}_{2}$ without aluminum present to complex the fluoride ions from dissolved $\mathrm{PuF}_{4}$. Then ANN would be added to complete the dissolution of remaining $\mathrm{PuF}_{4}$.

The remaining experiments optimized the conditions in this alternative two-step flowsheet and evaluated the effects of $\mathrm{MgO}$ sand in the converted cake mixture.

\section{Experiment \#5.0}

This experiment was another screening study to determine if both $\mathrm{PuF}_{4}$ and $\mathrm{PuO}_{2}$ could dissolve at lower temperatures without fluoride or aluminum initially present. Again, all solids dissolved without adding any fluoride or aluminum to the nitric acid solution.

\section{Experiment \#6.0}

This set of experiments started out with equal weights of the converted cake mixed with the MgO sand. The mass to volume ratio of $66 \%$ was closer to the upper limit of 75 set for the HB-Line dissolver. Results showed that all the $\mathrm{PuO}_{2}$ dissolved and about $22 \%$ of the $\mathrm{PuF}_{4}$ was in solution. The equilibrium fluoride concentration was 0.065 molar. However, when the solution cooled to room temperature, white solids formed which were later identified as $\mathrm{Mg}(\mathrm{NO} 3) 2$ and not aluminum nitrate.

\section{Experiments \#6A and \#6B}

These two additional experiments confirmed that a volume increase is sufficient to keep $\mathrm{Mg}(\mathrm{NO} 3) 2$ in solution at room temperature and that $\mathrm{PuF}_{4}$ will completely dissolve when sufficient aluminum is in solution.

\section{Experiments \#7.0, \#7A, and \#7B}

The significant differences between experiments \#6.0, \#6A, and \#6B with the \#7.0, \#7A, and \#7B series were the lower dissolving temperature for $\mathrm{PuO}_{2}\left(52^{\circ} \mathrm{C}\right)$ and the elimination of $\mathrm{MgO}$ sand. Although the results confirmed that the second two-step dissolution flowsheet will work at the lower solution temperature, it was the first indication that ANN white solids could precipitate at ambient temperatures when no magnesium was present. Again a volume increase was sufficient to redissolve the ANN.

\section{Experiments \#8.0, \#8A, and \#8B}

This series of experiments essentially duplicated the dissolving conditions used in the \#7.0, \#7A, and \#7B group. The mixture of solids dissolved was an equal weight of converted cake and $\mathrm{MgO}$ sand, similar to the \#6.0, \#6A, and \#6B experiments. However, this time both aluminum and 
magnesium nitrates precipitated from solution at room temperature. Both nitrates went back into solution by increasing the volume without reducing the acid concentration.

\section{Experiment \#9.0}

The final experiment used the remaining converted cake material and confirmed that complete dissolution of both $\mathrm{PuF}_{4}$ and $\mathrm{PuO}_{2}$ is possible at the lower dissolving temperatures when $\mathrm{PuF}_{4}$ solubility is not an issue.

\section{Conclusions}

(1) Complete dissolution of all $\mathrm{PuF}_{4}, \mathrm{PuO}_{2}$, and $\mathrm{MgO}$ in glovebox floor sweepings will occur using either of the two candidate two-step dissolution flowsheets tested in the laboratory. Because one of the candidate flowsheets involves fewer processing operations, it was selected for use by HB-Line. When using the selected flowsheet, the initial dissolution of the $\mathrm{PuF}_{4}, \mathrm{PuO}_{2}$, and $\mathrm{MgO}$ mixtures will be performed by heating the solutions between 55 and $65^{\circ} \mathrm{C}$ for a minimum of two hours in a 14.1 molar nitric acid solution. Under these conditions, all the $\mathrm{PuO}_{2}$ and $\mathrm{MgO}$ sand and only a portion of the $\mathrm{PuF}_{4}$ will dissolve. The maximum fluoride concentration reached during this initial dissolution step was about 0.07 molar.

The second dissolution. step involves adding sufficient ANN to maintain at least a one-to-one aluminum to fluoride mole ratio. The solution is then heated between 75 and $85^{\circ} \mathrm{C}$ for at least two hours. Under these conditions all remaining $\mathrm{PuF}_{4}$ will dissolve.

(2) The potential for precipitation exists for either or both magnesium nitrate and aluminum nitrate in the dissolver or during the transfer to the product hold tank. During the flowsheet development program, both nitrate salts independently or in combination precipitated when dissolver solutions cooled to ambient temperatures. In all cases, just increasing the volume was sufficient to redissolve the nitrate solids. An alternative approach would be to keep solutions at elevated temperatures in the dissolver and during the transfer operations. Precipitation in the product hold tank should not occur if sufficient dilution volume is present before the transfer operation begins.

As part of a pre-operational test program, it is suggested that, for example, a $\mathrm{kg}$ of $\mathrm{MgO}$ sand be dissolved using the selected flowsheet operations and conditions. Then the subsequent acid and aluminum adjustments be made and transfers to the product hold tank be performed to confirm that nitrate salts will not precipitate during any of these operations.

(3) Minimal corrosion of the HB-Line dissolver during these dissolving operations is expected. This is because the dissolving temperature is only 55 to $65^{\circ} \mathrm{C}$ when the fluoride concentration is at 0.07 molar and is only 75 to $85^{\circ} \mathrm{C}$ when the fluoride is complexed at a one-to-one aluminum to fluoride mole ratio. 


\section{References}

1. J. H. Gray, D. G. Karraker, T. S. Rudisill, G. T. Chandler, "Canyon Dissolution of Sand, Slag, and Crucible Residues," WSRC-TR-97-00367, Rev. 0, December 1997. 
TABLE 1. TEST RESULTS FROM DISSOLUTION OF GLOVEBOX FLOOR SWEEPINGS

\begin{tabular}{|c|c|c|c|c|c|c|c|c|}
\hline $\begin{array}{c}\text { EXPT } \\
\#\end{array}$ & $\begin{array}{c}\text { SOLIDS/ } \\
\text { LIQUID } \\
\text { RATIO } \\
(\mathrm{g} / \mathrm{l})\end{array}$ & $\begin{array}{c}\text { NITRIC } \\
\text { ACID } \\
\text { CONC. } \\
(\mathrm{mol} / \mathrm{)})\end{array}$ & $\begin{array}{c}\text { Al } \\
\text { CONC. } \\
(\mathrm{mol} / \mathrm{l})\end{array}$ & $\begin{array}{l}\text { FLUORIDE } \\
\text { CONC. } \\
(\mathrm{mol} / 1)\end{array}$ & $\begin{array}{l}\text { DISSOL. } \\
\text { TEMP. } \\
\text { (deg.C) }\end{array}$ & $\begin{array}{l}\text { SOLIDS } \\
\text { DISSOL. }\end{array}$ & $\begin{array}{c}\text { DISSOL. } \\
\text { TIME } \\
\text { (min.) }\end{array}$ & $\begin{array}{c}\mathrm{Pu} \\
\text { CONC. } \\
(\mathrm{g} / \mathrm{l})\end{array}$ \\
\hline 1.0 & 5.0 & 10.5 & 0.0 & 0.037 & 90 & all & 10 & 3.7 \\
\hline 2.0 & 50 & 10.5 & 0.0 & incompl. & 85 & $\begin{array}{c}\text { all } \mathrm{PuO}_{2} \\
\text { some } \mathrm{PuF}_{4}\end{array}$ & 30 & incomp \\
\hline $2 \mathrm{~A}$ & 37.5 & 7.9 & 0.39 & 0.33 & 85 & $\begin{array}{c}\text { all Pu } \\
\text { ANN pptd.? }\end{array}$ & 30 & 27.5 \\
\hline $2 B$ & 30 & 8.4 & 0.31 & 0.26 & 80 & $\begin{array}{c}\text { all } \mathrm{Pu} \\
\text { no ANN } \\
\text { pptd. } \\
\text { Si pptd. }\end{array}$ & 30 & 22 \\
\hline 3.0 & 50 & 10.5 & 0.39 & 0.37 & 80 & $\begin{array}{l}\text { no } \mathrm{PuO}_{2} \\
\text { all } \mathrm{PuF}_{4}\end{array}$ & 30 & 26.5 \\
\hline $3 \mathrm{~A}$ & 44.4 & 9.3 & 0.35 & 0.33 & 108 & $\begin{array}{l}\text { no } \mathrm{PuO}_{2} \\
\text { all } \mathrm{PuF}_{4}\end{array}$ & 30 & 23.5 \\
\hline $3 B$ & N.A. & 14.1 & 0.0 & 0.0 & 80 & none & 30 & 0.0 \\
\hline $3 C$ & N.A. & 14.1 & 0.0 & 0.05 & 80 & all $\mathrm{PuO}_{2}$ & 30 & 20.5 \\
\hline 4.0 & 50 & 14.1 & 0.0 & 0.06 & 80 & $\begin{array}{c}\text { all } \mathrm{PuO}_{2} \\
\text { some } \mathrm{PuF}_{4}\end{array}$ & 30 & 12.9 \\
\hline $4 \mathrm{~A}$ & 37.5 & 10.5 & 0.39 & 0.33 & 80 & $\begin{array}{l}\text { all } \mathrm{PuO}_{2} \\
\text { all } \mathrm{PuF}_{4}\end{array}$ & 30 & 27.5 \\
\hline 5.0 & 5.0 & 14.1 & 0.0 & 0.037 & 70 & all & 30 & 3.7 \\
\hline 6.0 & 66.7 & 14.1 & 0.0 & 0.065 & 80 & $\begin{array}{c}\text { all } \mathrm{MgO} \\
\text { all } \mathrm{PuO}_{2} \\
\text { some } \mathrm{PuF}_{4} \\
\mathrm{Mg}(\mathrm{NO} 3) 2 \\
\text { pptd. }\end{array}$ & 30 & 12.9 \\
\hline $6 \mathrm{~A}$ & 40 & 14.1 & 0.0 & 0.04 & 80 & $\begin{array}{c}\text { all } \\
\mathrm{Mg}(\mathrm{NO} 3) 2 \\
\text { all } \mathrm{PuO}_{2} \\
\text { some } \mathrm{PuF}_{4}\end{array}$ & 30 & 7.7 \\
\hline $6 B$ & 33.3 & 11.8 & 0.26 & 0.12 & 80 & all & 30 & 6.4 \\
\hline
\end{tabular}


WSRC-TR-98-00029

Revision 0

TABLE $1 . \quad$ CONTINUED

\begin{tabular}{|c|c|c|c|c|c|c|c|c|}
\hline $\begin{array}{c}\text { EXPT } \\
\#\end{array}$ & $\begin{array}{c}\text { SOLIDS/ } \\
\text { LIQUID } \\
\text { RATIO } \\
\text { (g/1) }\end{array}$ & $\begin{array}{c}\text { NITRIC } \\
\text { ACID } \\
\text { CONC. } \\
(\mathrm{mol} / 1)\end{array}$ & $\begin{array}{c}\mathrm{Al} \\
\mathrm{CONC} . \\
(\mathrm{mol} / \mathrm{l})\end{array}$ & $\begin{array}{l}\text { FLUORIDE } \\
\text { CONC. } \\
(\mathrm{mol} / \mathrm{l})\end{array}$ & $\begin{array}{l}\text { DISSOL. } \\
\text { TEMP. } \\
\text { (deg.C) }\end{array}$ & $\begin{array}{l}\text { SOLIDS } \\
\text { DISSOL. }\end{array}$ & $\begin{array}{l}\text { DISSOL. } \\
\text { TIME } \\
\text { (min.) }\end{array}$ & $\begin{array}{c}\mathrm{Pu} \\
\text { CONC. } \\
(\mathrm{g} / \mathrm{l})\end{array}$ \\
\hline 7.0 & 66.7 & 14.1 & 0.0 & 0.07 & 52 & $\begin{array}{l}\text { all } \mathrm{PuO}_{2} \\
\text { some } \mathrm{PuF}_{4}\end{array}$ & 15 & 17.3 \\
\hline $7 \mathrm{~A}$ & 50 & 10.5 & 0.39 & 0.44 & 80 & $\begin{array}{c}\text { all } \mathrm{PuO}_{2} \\
\text { all } \mathrm{PuF}_{4} \\
\text { ANN pptd. }\end{array}$ & 30 & 36.7 \\
\hline $7 \mathrm{~B}$ & 36.4 & 10.5 & 0.28 & 0.32 & 80 & all & 30 & 26.7 \\
\hline 8.0 & 66.7 & 14.1 & 0.0 & 0.07 & 60 & $\begin{array}{c}\text { all } \mathrm{MgO} \\
\text { all } \mathrm{PuO}_{2} \\
\text { some } \mathrm{PuF}_{4} \\
\mathrm{Mg}(\mathrm{NO} 3) 2 \\
\text { pptd. }\end{array}$ & 30 & 8.7 \\
\hline $8 \mathrm{~A}$ & 50 & 10.5 & 0.39 & 0.22 & 85 & $\begin{array}{c}\text { all } \mathrm{PuO}_{2} \\
\text { all } \mathrm{PuF}_{4} \\
\mathrm{Mg} . \mathrm{Al} \\
\text { nitrates } \\
\text { pptd. }\end{array}$ & 30 & 18.4 \\
\hline $8 B$ & 33.3 & 10.5 & 0.26 & 0.15 & ambient & all & N.A. & 12.3 \\
\hline 9.0 & 6.8 & 14.1 & 0.0 & 0.06 & 60 & all & 60 & 5.0 \\
\hline
\end{tabular}




\section{Distribution}

R. M. Mobley, 704-2H

S. A. Yano, 704-2H

D. W. Southmayd, 704-2H

P. R. Pritchard, 221-HBL

W. L. Isom, 704-2H

J. S. Evans, 703-F

F. R. Graham, 773-A

J. H. Gray, 773-A

J. Greggi, Jr.,707-F

R. T. Burns, 221-HBL

J. W. Barber, 704-2H

R. H. Smith, 704-2H

J. R. Knight, 773-A

E. A. Kyser, 773-A

R. R. Livingston, 773-A

D. G. Karraker, 773-A

R. A. Vohden, 221-13H

F. W. Schoenfelder, 221-13H

A. M. Murray, 773-A

B. L. Tomlin, 221-13H

T. S. Rudisill, 773-A

J. B. Schaade, 703-F

W. R. Jeffords, 221-HBL

D. Stimac, 703-F

M. C. Thompson, 773-A

G. J. Winkler, 703-F

C. R. Wolfe, 773-A

A. T. Masterson, 221-HBL

J. Mancilla, 221-13H

CHTS Files, 773-A 